\title{
MLL/SEPT6 Fusion Protein
}

National Cancer Institute

\section{Source}

National Cancer Institute. MLL/SEPT6 Fusion Protein. NCI Thesaurus. Code C99356.

A fusion protein encoded by the MLL/SEPT 6 fusion gene. This protein is comprised of the $\mathrm{N}$-terminal half of the histone-lysine $\mathrm{N}$-methyltransferase MLL protein, including the AT hook DNA binding domain and the DNA methyltransferase domain, fused to most of the septin-6 protein. 